\title{
THE MODERNIZATION OF THE MRZEZYNO SEAPORT. APPL YING SIMULATION STUDIES TO DEFINE THE VARIANTS OF THE EXPANSION OF THE ENTRANCE BREAKWATER
}

\begin{abstract}
Objective reasons, such as climatic changes, larger vessels, sometimes the impracticality of the current solutions, determine the interest of decision-makers in rebuilding the existing ports and breakwaters. Tested simulation models allow for a thorough analysis of the possible modernization variants taking into account the variability of basic parameters. The article presents research results related to the optimization of the Mrzezyno seaport with respect to navigation safety and the possibility of larger vessels calling at the port after its modernization.

In the paper, real time simulation methods based on manoeuvre simulators were applied. Two different variants that can be implemented from the technical point of view were studied. Following a multidimensional analysis that took into consideration increased comfort of ship manoeuvres in the port and navigation safety, one variant was indicated as the optimum. The aim of the research results is to help design new solutions in the case of the modernization of the Mrzezyno seaport.
\end{abstract}

\section{Keywords:}

model of manoeuvring a ship, navigation safety, designing seaports, breakwater optimization.

\section{INTRODUCTION}

The modernization and expansion of the existing seaports and breakwaters is forced not only by the aging of these structures or creeping climatic changes, 
but also the quest for new spots on the coast where larger passenger boats could call at as a result of the development of tourism. The creation of a port infrastructure has a large influence on the onshore economy in its vicinity, thus it seems plausible to carry out a study that — in case such a need arises — would allow for the expansion of the scope of a port's operations.

At the stage of preliminary analyses, two concepts of building a new breakwater and entrance to the port were formulated. Simulations studies carried out in the Mrzezyno seaport were aimed at evaluating the navigation safety of the two proposals, at the same time taking into account their practicality.

The main research objectives were the following:

- defining the maximum vessels for the modernized entrance to the Mrzezyno seaport;

- defining the breadth of approach fairways to the seaport for various conditions;

- defining the boundary safe conditions for operation of the solutions for entering the port under consideration (wind, waves);

- defining the tactics for manoeuvring while entering the port and in the port.

\section{FEATURES OF NAVIGATION CONDITIONS FOR THE MRZEZYNO SEAPORT AND VARIANTS OF THE MODERNIZATION OF THE MRZEZYNO PORT}

The seaport located on the west coast of Poland near the estuary of the Rega river is protected with two breakwaters stretching into the sea. The east breakwater is $206 \mathrm{~m}$ long, and the west one - $327 \mathrm{~m}$ long. Approach fairway in the bearing of about $160^{\circ}$. The depths in the wharfs and docks may undergo changes. The acceptable draught in the port is about $2.5 \mathrm{~m}$, and about $1.8 \mathrm{~m}$ in the marina. The Mrzezyno seaport consists of the entrance canal and port canal. The entrance canal spreads over $292 \mathrm{~m}$ of length, and the full breadth of the entrance canal in the bottom in about $50 \mathrm{~m}$. The port canal of $358 \mathrm{~m}$ of length is an extension of the entrance canal. The port canal ends with a turning basin of 82 $\mathrm{m}$ in diameter. In the final stretch of the canal on the east side there are parking spaces and loading bays. In the vicinity of the customs wharf the breadth in the bottom is $36 \mathrm{~m}$. The maximum breadth is $87 \mathrm{~m}$ and is located in the area of the Turing basin. The designed depth of the port canal is $3.8 \mathrm{~m}$. 
The current theoretical depths of the sea lane are $3.50 \mathrm{~m}$ in the entrance stretch, and $3.0 \mathrm{~m}$ in the port canal. The designed depths are $4.60 \mathrm{~m}$ for the entrance stretch and $3.80 \mathrm{~m}$ for the port canal.

In the vicinity of Mrzezyno the 10-metre isobath is about $3 \mathrm{~km}$ away from the shore. Where the depth is less than $10 \mathrm{~m}$, the bottom undergoes constant changes due to hydrodynamic phenomena.

Figure 1 presents the entrances to the port with depth contours and navigation marks.

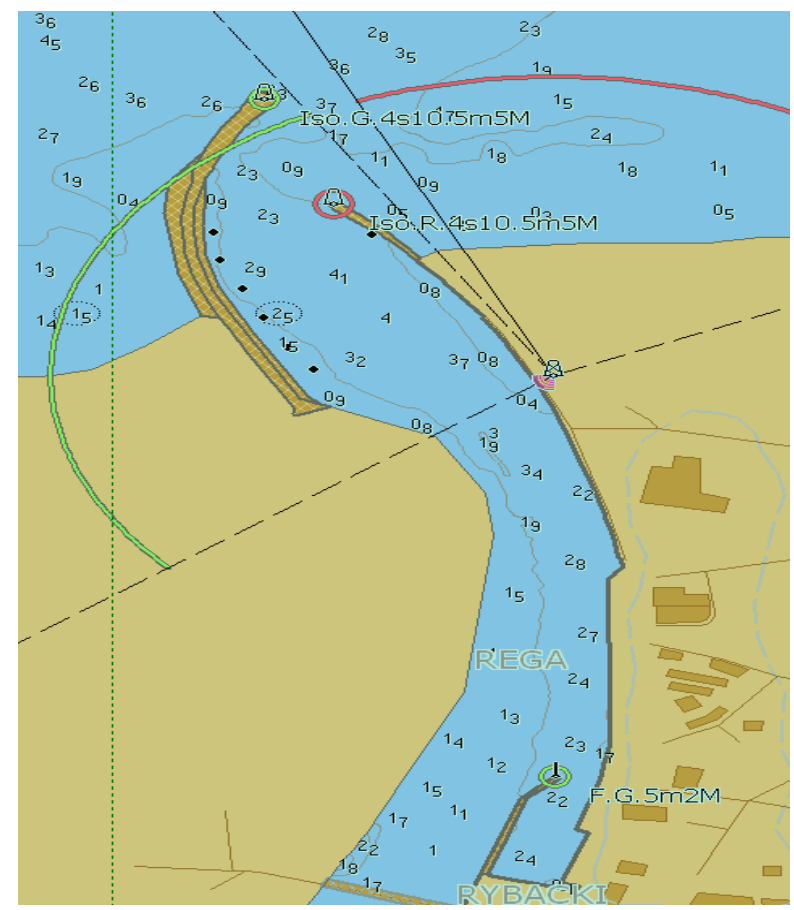

Fig. 1. The current entrance to the port, depth contours and navigations marks

Figure 7 presents two concept variants of the modernization of the port and breakwater: 4B and 3. They assume that additional protective breakwaters in a symmetrical structure will be built and the existing east breakwater will be partially removed (variant 4B) or fully preserved (variant 3), and the west breakwater will be fully preserved. The variants assume that a sea lane of $50 \mathrm{~m}$ of length will be built that will run after passing the curve in the port where the existing breakwater is to $40 \mathrm{~m}$ and $30 \mathrm{~m}$, and a turning basin of $90 \mathrm{~m}$ of diameter. 


\section{HYDROMETEOROLOGICAL CONDITIONS}

A selection of hydrometeorological conditions that influence the safety of ship manoeuvres in water approach fairways to the Mrzezyno port and within this port's docks may include:

1. Winds - the majority of winds are SW and W; their frequency is 35-50\%. In every situation, atmospheric conditions over a given area are decisive.

2. Waves - the largest waves swell during long-lasting storms. The most significant wave in a deep area is a wave of up to $1 \mathrm{~m}$ of height (maximum average wave), and period of between 0 to $7 \mathrm{~s}$, and length of 50-80 m. On stormy days, waves can reach $3 \mathrm{~m}$. The longest wave periods close to Mrzezyno are $17 \mathrm{~s}$.

3. Water level - average water level defined for the port is $507 \mathrm{~cm}$ (according to the zero level in Amsterdam). Strong winds from the west cause the water level to increase by about $70-80 \mathrm{~cm}$ with respect to the average level.

4. Icing - due to the strong current, the port canal freezes over only when winters are severe. The entrance to the port may be blocked for temporary, short-term periods by ice floes accumulated in the littoral zone, as a result of a long-blowing wind from the north west to north to north east.

5. Currents - depending on the wind direction, littoral currents flow to the north east or north west. The speed of the current depends of the strength and duration of a wind blowing from one direction and can achieve 3 knots.

6. Visibility and fog.

\section{THE CHARACTERISTICS OF THE VESSELS CALLING AT THE MRZEZYNO PORT OR OF THOSE THAT WILL ULTIMATELY USE IT}

In accordance with the binding port regulations in Mrzezyno, the maximum length of ships that can call at the port is $12 \mathrm{~m}$, whereas the maximum breadth of the vessels cannot exceed $4 \mathrm{~m}$. Currently, the vessels used in the port are fishing boats, small passenger vessels and dredgers.

Due to the dynamic growth of sea tourism, in the not too distant future the port may be obliged to accept vessels whose size is $L=60 \mathrm{~m}, B=12 \mathrm{~m}$, $T=2.5 \mathrm{~m}$. Such vessels are used for seagoing holiday cruises on the Baltic often out of the Tricity (e.g. the Ustka - Bornholm line). Table 1 shows the parameters 
of the structure of the ship that was used as the basis for the research. The vessel layout is presented in Figure 2.

Tab. 1. The main parameters of a characteristic ship $(L=60 \mathrm{~m})$ operating on the Baltic Sea

\begin{tabular}{|l|l|}
\hline \multicolumn{1}{|c|}{ Parameter } & \\
\hline Length - LOA & $60 \mathrm{~m}$ \\
\hline Breadth & $12 \mathrm{~m}$ \\
\hline Draft & $2.5 \mathrm{~m}$ \\
\hline Machinery & total $2 \times 1.200 \mathrm{~kW}$ at $900 \mathrm{rpm}$ \\
\hline Speed & approx. $18 \mathrm{kn}($ at $90 \%)$ \\
\hline Rudder & $1 \times 35$ deg/area $=2.7 \mathrm{~m}^{2} /$ conventional \\
\hline Bowthruster & $150 \mathrm{~kW}$ \\
\hline
\end{tabular}

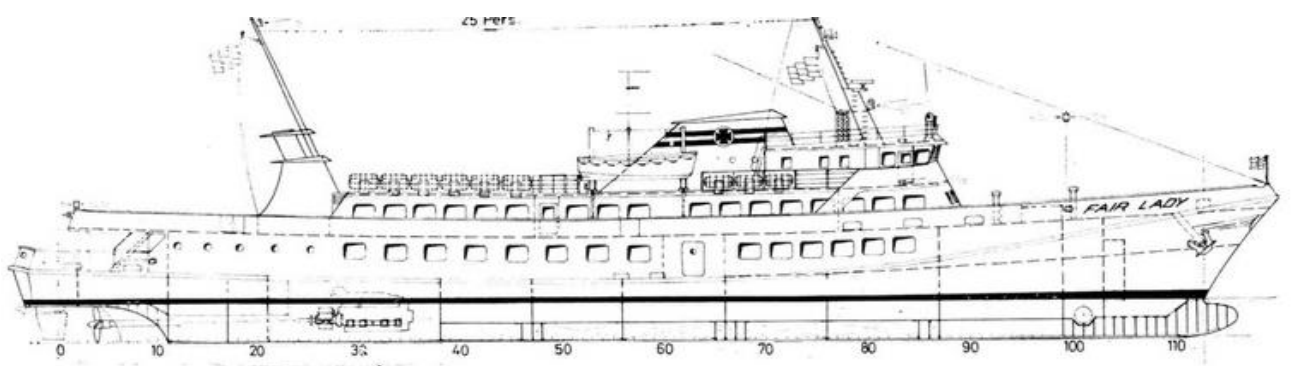

Fig. 2. The layout of the m/s 'Lady Assa' vessel (former 'Adler Baltica')

[http://www.naszbaltyk.com]

\section{BUILDING AND VERIFYING THE SMART MODEL USED IN SIMULATION STUDIES}

At the Maritime University in Szczecin, a whole family of analytical and experimental models of ship motions was designed [Gucma S., 1990]. In this paper, the SMART model was used, but due to the lack of precise manoeuvre data of the vessels studied, they were interpolated from empirical relations.

\section{A mathematical model of ship movement}

The model used for studying ship motions belongs to force models of modular structure, i.e. one where hydrodynamic forces of the hull, forces from 
propelling and steering units, external forces and other are separated as independent elements of the model and summed up accordingly in the final phase as longitudinal, lateral and rotational forces [Gucma S., 2008]:

- propeller pressure;

- propeller lateral operation;

- carrying and steer resistance;

- bow thrusters operation;

- current, wind and ice;

- sucking and rotational torque of the bank effect;

- braking of shallow water;

- hawser and anchor operation;

- wharf reaction and friction between the wharf and the ship hull;

- tugs;

- and other resulting from the characteristics of each propelling and steering device.

The scheme of how the model works is presented in Figure 3.

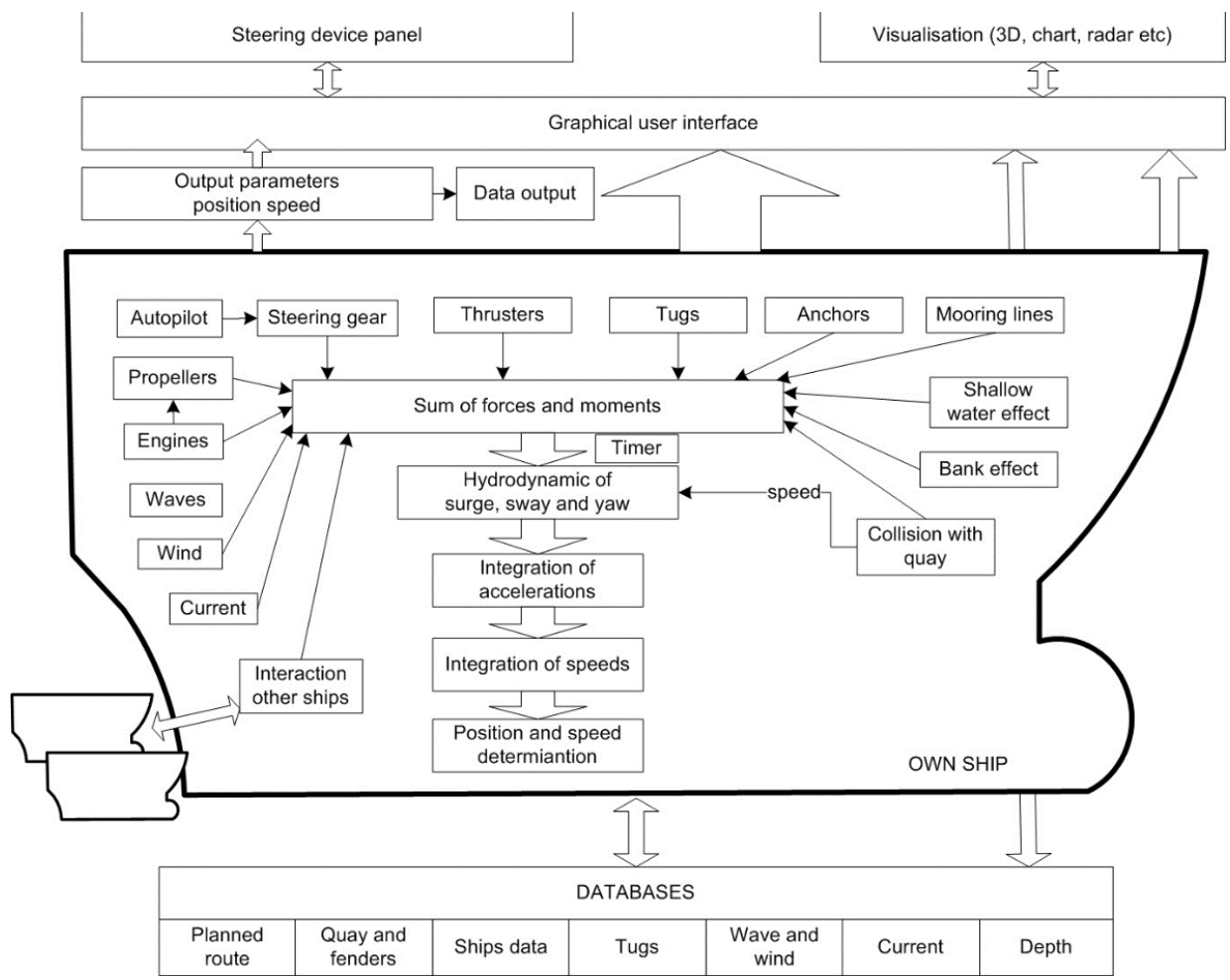

Fig. 3. The main functional diagram of simulation model 


\section{A detailed description of the SMART mathematical model}

In the paper, labels that are most frequently used in the hydrodynamics of watercraft manoeuvring were applied:

- $O x_{0} y_{0 z_{0}}$ (fixed) related to the land for positioning a watercraft, understood both as its location ( $x-y$ position) on the earth and its orientation;

- Mxyz (mobile) related to the watercraft for registering the motion dynamics (change of the motion speed as a result of external forces).

\section{Equations of motion}

Simplifying the above model by removing the effects that are less important in manoeuvring, it can be brought down to a set of differential equations whose results show the change of a ship's speed with regard to the basin bottom (' $\left.v^{g '}\right)$ for three degrees of freedom.

The bases for the mathematical model of manoeuvre motions of a watercraft used (differential motion equations and the structure of function relations of each external interaction) were presented in detail among others in [Artyszuk, 2005] and correspond to the current state of knowledge in this field.

$$
\begin{aligned}
& \left\{\begin{array}{l}
\left(m+m_{11}\right) \frac{d v_{x}^{g}}{d t}=\left(m+c_{m} m_{22}\right) v_{y}^{g} \omega_{z}+\left(m_{11}-c_{m} m_{22}\right) v_{y}^{c} \omega_{z}+F_{x} \\
\left(m+m_{22}\right) \frac{d v_{y}^{g}}{d t}=-\left(m+m_{11}\right) v_{x}^{g} \omega_{z}+\left(m_{11}-m_{22}\right) v_{x}^{c} \omega_{z}+F_{y} \\
\left(J_{z}+m_{66}\right) \frac{d \omega_{z}}{d t}=-\left(m_{22}-m_{11}\right)\left(v_{x}^{g}-v_{x}^{c}\right)\left(v_{y}^{g}-v_{y}^{c}\right)+M_{z}
\end{array} ;\right. \\
& \frac{d x_{0}}{d t}=v_{N S}^{g} \quad, \quad \frac{d y_{0}}{d t}=v_{E W}^{g} \quad, \quad \frac{d \psi}{d t}=\omega_{z} ; \\
& {\left[\begin{array}{c}
v_{N S}^{g} \\
v_{E W}^{g}
\end{array}\right]=\left[\begin{array}{cc}
\cos \psi & -\sin \psi \\
\sin \psi & \cos \psi
\end{array}\right] \cdot\left[\begin{array}{c}
v_{x}^{g} \\
v_{y}^{g}
\end{array}\right],}
\end{aligned}
$$

where:

$v_{x}^{g}, v_{y}^{g}, v_{z}^{g}$ - ship surge, sway and yaw velocity over the ground,

$x_{0}, y_{0}, z_{0}-$ position Cartesian coordinates and heading,

$m \quad$ - ship mass, 
$m_{11}, m_{22}, m_{66}$ - added masses,

$c_{m} \quad$ - empirical factor,

$F_{x}, F_{y}, M_{z} \quad$ - external excitations (resultant/total surge, sway force and yaw moment), generally consisting of the following items (denoted by additional subscripts) and being generally the functions of ship speed through the water $\left(' v_{w}^{\prime}\right)$ :

$$
\begin{gathered}
\left\{\begin{aligned}
F_{x}= & F_{x H}+\sum_{i=1}^{2} F_{x P i}+\sum_{i=1}^{2} F_{x R i}+F_{x A}+F_{x W V 2} \\
F_{y}= & F_{y H}+\sum_{i=1}^{2} F_{y P i}+\sum_{i=1}^{2} F_{y R i}+F_{y A}+F_{y W V 2}+\sum_{i=1}^{2} F_{y L T i} \\
M_{z}= & M_{z H}+\sum_{i=1}^{2} M_{z P i}+\sum_{i=1}^{2} M_{z R i}+M_{z A}+M_{z W V 2}+\sum_{i=1}^{2} M_{z L T i}
\end{aligned}\right. \\
\left\{\begin{array}{l}
F_{x}=F_{x}\left(v_{x}^{w}, v_{y}^{w}, \omega_{z}\right) \\
F_{y}=F_{y}\left(v_{x}^{w}, v_{y}^{w}, \omega_{z}\right) ; \\
M_{z}=M_{z}\left(v_{x}^{w}, v_{y}^{w}, \omega_{z}\right)
\end{array}\right. \\
{\left[\begin{array}{c}
v_{x}^{c} \\
v_{y}^{c}
\end{array}\right]=\left[\begin{array}{cc}
\cos \psi & \sin \psi \\
-\sin \psi & \cos \psi
\end{array}\right] \cdot\left[\begin{array}{l}
\left|\vec{v}^{c}\right| \cos \gamma_{c} \\
\vec{v}^{c} \mid \sin \gamma_{c}
\end{array}\right],}
\end{gathered}
$$

where $\left|\vec{v}^{c}\right|$ and $\gamma_{c}$ represent the velocity and geographical direction of the water current (a uniform current by default).

\section{The verification of the data used for simulation in the SMART program}

To optimise the model, author's software operating on the basis of MS Excel 2000 calculation spreadsheet and the mode of accelerated time of the above-mentioned SMART program were used. The visualization of the convergence of predictions and real data player a significant role.

The correctness of the prediction code of the model used was confirmed by several years' research during classes in manoeuvring a ship for students of the 
Maritime University of Szczecin and research works of a scientific team of marine traffic engineering, among others [Gucma L., 2005].

Also, hydrodynamic coefficients of particular forces and moments were tentatively defined according to the data published in the literature based on model research of the hull (upper and lower works). In the case of a glaring disproportion, an adequate extrapolation of the research results to the technical and exploitation conditions of a modelled ferry were used.

The verification results for the model of the ship studied carried out based on the commonly accepted manoeuvre characteristics for verification: speed, braking and acceleration, circulation and zigzag tests confirmed the correctness of the optimization program model built.

\section{The interface of the model (depicting and controlling the simulation model)}

Figure 4 presents the interface of the model. It contains information about the location of the post, depth contours of the basin, information on the state of the ship and hydrometeorological conditions, and control elements for steering the ferry. The model is implemented in the Delphi ${ }^{\text {TM }}$ environment with the use of the Object Pascal language and in the Visual $\mathrm{C}^{\mathrm{TM}}$ environment with the use of the $\mathrm{C}++$ language.

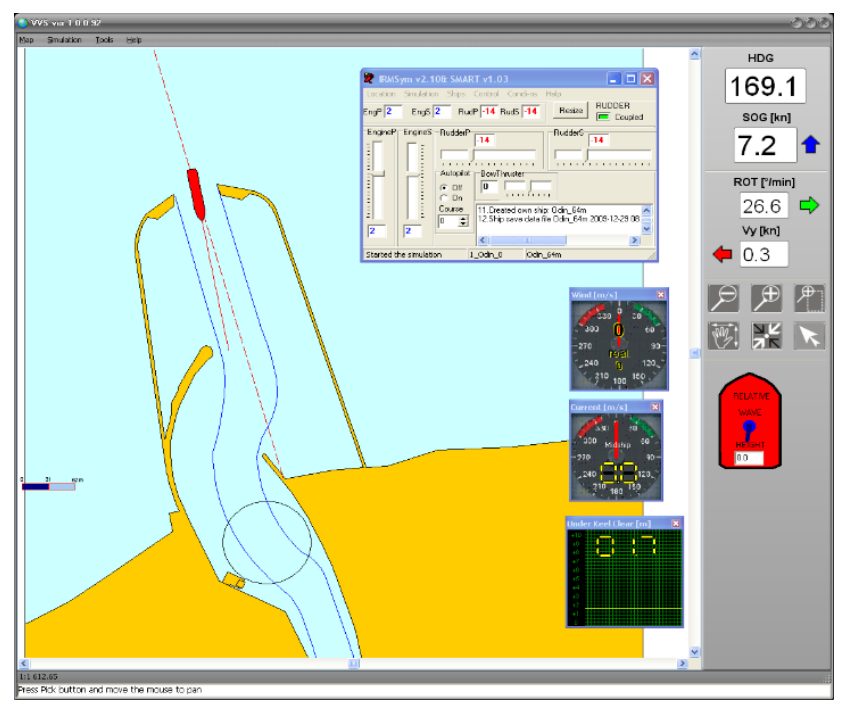

Fig. 4. A simulation model for ship motions, entrance to the port for the first stage of research 


\section{ASSUMPTIONS FOR SIMULATION STUDIES AND DATA PROCESSING}

The most important objective of the modernization of the port and breakwater in Mrzezyno is to ensure access for passenger boats of up to $60 \mathrm{~m}$ of length. The exploitation conditions of the port planned in Mrzezyno can be defined as follows:

- the port will be exploited throughout the year;

- the port will accept passenger boats of short sea shopping of up to $L_{C}=60 \mathrm{~m}$ of length and maximum draught of up to $T=2.5 \mathrm{~m}$;

- the approaching, parking and departing of ships will depend on hydrometeorological conditions, with extreme exploitation conditions defined as wind of $8^{\circ} \mathrm{B}$ blowing from the sea;

- the port will make it possible for the ships to turn;

- the use of tugs will depend on the type of propulsion and steering devices of the vessel.

Simulation studies are very widely used. Hydrodynamic models are more and more reliable. Without efficient processing of statistical data, however, it will not be possible to draw any conclusions for the experiments carried out. The most important factor is a safe horizontal area necessary for manoeuvres for navigators [Gucma L., 2005], [Gucma L., 2012], [Irribaren J.R., 1999]. In such a model, we assume that the ship moves along the indicated route (Fig. 5).

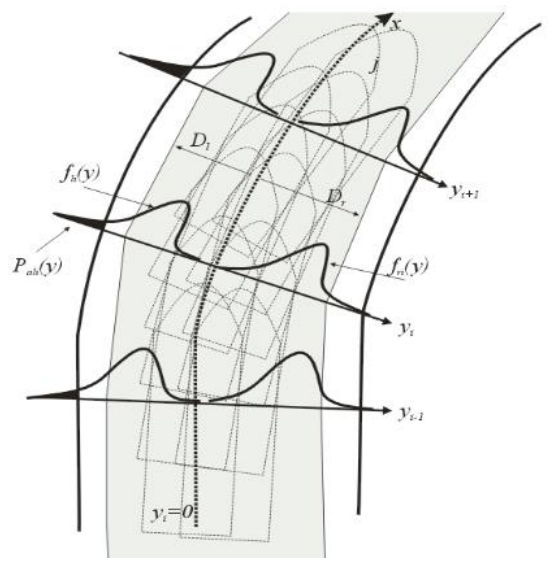

Fig. 5. The probabilistic concept of defining a safe area 
Simulation studies consist it carrying out a reliable number of series of manoeuvre trials (entrance/turning) for the variants studied that define the problem being solved. The comparison of results for each variant is conducted with the criteria of sailing safety.

The assumptions of simulation studies are as follows:

- testing and verifying, at least two alternative port projects designed by two independent project teams;

- research was carried out for entrance manoeuvres to the port passing the sea lane till going past the turning basin, without turning;

- the series of exiting the port were not carried out as these are manoeuvres that are much simpler from the navigation point of view;

- the manoeuvres were carried out without tugs;

- the tests into the entrance manoeuvres started in the distance of over $1.000 \mathrm{~m}$ away from the entrance beacons, with the initial speed of 7 knots $\pm 1 \mathrm{kn}$; the tests finished after the turning basin was passed by;

- number of manoeuvres: 3 (captains) and 1 (testers) successful crossings in a series;

- first, series at zero conditions were carried out;

- the breakwaters and sea lanes were modelled as so-called 'soft' i.e. a ship can pass over them but only if necessary;

- while approaching from the sea, the ship was supposed to keep to the middle of the sea lane;

- fixed simulated depth about $5 \mathrm{~m}$;

- the wave and current were obstructed accordingly in line with the results of model trials of rippling and the model of wind obstruction.

\section{Simulation series with hydrometeorological con- ditions assumed}

In the studies, the following manoeuvre conditions as far as wind speed is concerned were assumed:

- zero, whose objective is to compare the size of manoeuvre areas against conditions with wind;

- wind of $11 \mathrm{~m} / \mathrm{s}$ (bottom force range $6^{\circ} \mathrm{B}$ );

- wind of $17 \mathrm{~m} / \mathrm{s}$ (bottom force range $8^{\circ} \mathrm{B}$ ). 
Two wind directions were assumed:

- NW as a wind from lateral directions with respect to the entrance, i.e. the most difficult wind at entering a port from the navigational point of view;

- NE as a wind from the direction of the stern that can hinder the entrance by causing moment from the wave and wind.

The height of the significant wave was assumed according to the direction of the wind and proportionally to its speed, respectively:

- $0 \mathrm{~m}$ for zero conditions;

- $0.9 \mathrm{~m}$ for the wind of $11 \mathrm{~m} / \mathrm{s}$;

- $1.6 \mathrm{~m}$ for the wind of $17 \mathrm{~m} / \mathrm{s}$.

In total, 10 simulations series were carried out with 17 to 18 passages in each. Their detailed assumptions are presented in Table 2. Sample simulation results are presented in Figure 6.

Tab. 2. A detailed plan for the conditions of conducting simulation trials

\begin{tabular}{|c|c|c|c|c|c|}
\hline $\begin{array}{l}\text { Series } \\
\text { No. }\end{array}$ & $\begin{array}{l}\text { Layout of } \\
\text { the Mrzezyno port } \\
\text { (map) }\end{array}$ & $\begin{array}{c}\text { Type of } \\
\text { the manoeuvre }\end{array}$ & Wind & Wave & Current \\
\hline 1 & \multirow{5}{*}{ Mrzezyno variant $4 \mathrm{~b}$} & \multirow{10}{*}{ 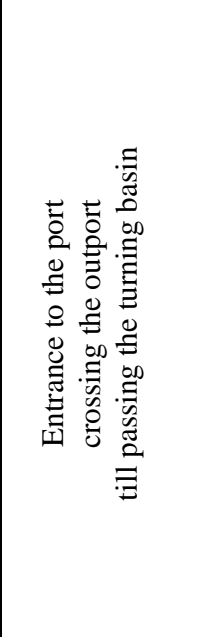 } & 0 & 0 & 0 \\
\hline 2 & & & NW $11 \mathrm{~m} / \mathrm{s}(6 \mathrm{~B})$ & about $0.9 \mathrm{~m}$ & initial $1 \mathrm{w}$ \\
\hline 3 & & & NW $17 \mathrm{~m} / \mathrm{s}(8 \mathrm{~B})$ & about $1.6 \mathrm{~m}$ & as above \\
\hline 4 & & & $\mathrm{NE} 11 \mathrm{~m} / \mathrm{s}$ & about $0.9 \mathrm{~m}$ & as above \\
\hline 5 & & & $\mathrm{NE} 17 \mathrm{~m} / \mathrm{s}$ & about $1.6 \mathrm{~m}$ & as above \\
\hline 6 & \multirow{5}{*}{ Mrzezyno variant 3} & & 0 & 0 & 0 \\
\hline 7 & & & $\mathrm{NW} 11 \mathrm{~m} / \mathrm{s}(6 \mathrm{~B})$ & about $0.9 \mathrm{~m}$ & initial $1 \mathrm{w}$ \\
\hline 8 & & & NW $17 \mathrm{~m} / \mathrm{s}(8 \mathrm{~B})$ & about $1.6 \mathrm{~m}$ & as above \\
\hline 9 & & & $\mathrm{NE} 11 \mathrm{~m} / \mathrm{s}$ & about $0.9 \mathrm{~m}$ & as above \\
\hline 10 & & & $\mathrm{NE} 17 \mathrm{~m} / \mathrm{s}$ & about $1.6 \mathrm{~m}$ & as above \\
\hline
\end{tabular}


a)

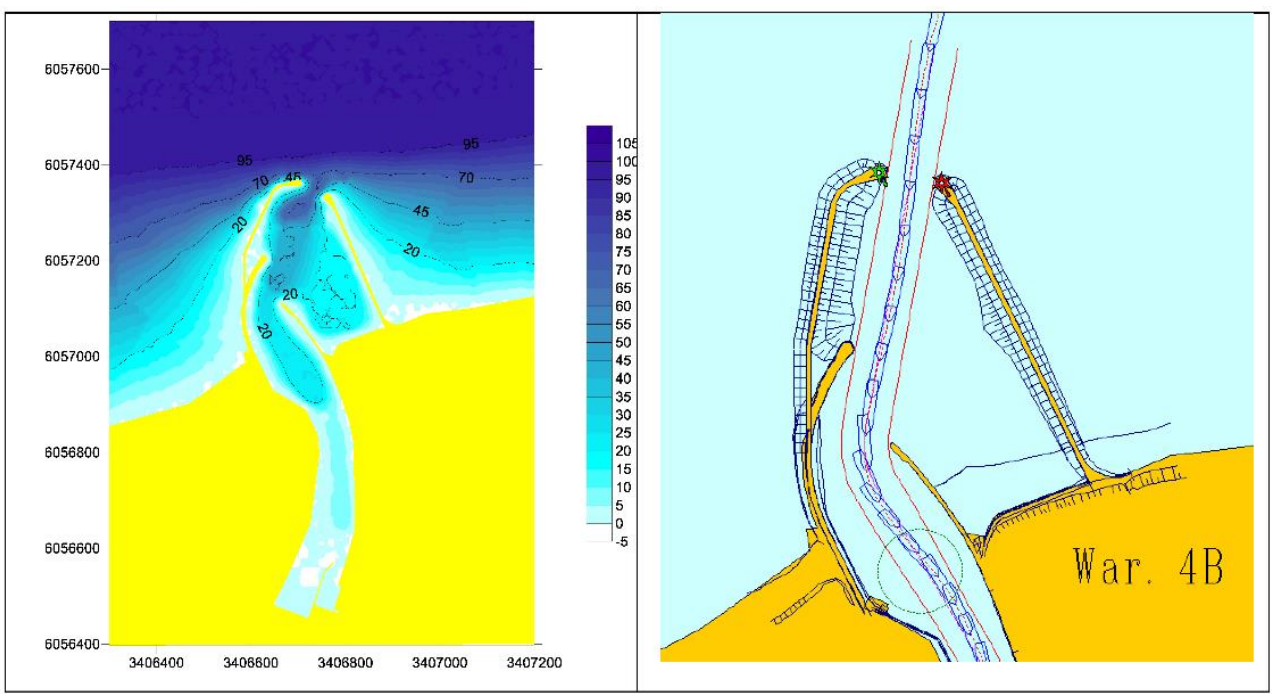

Fig. 6: a) Sample simulation results for the relative wave heights for directions NW;

b) single simulation passages

\section{RESEARCH RESULTS}

All simulation tests were carried out by qualified captains and pilots experienced in this type of ships and manoeuvres. Simulation data was registered and analyzed. The analysis for the results of simulation tests was carried out for one criterion: the breadth of the traffic lane. The breadth of traffic lanes was calculated on the average level, the $95 \%$ reliability level and the maximum level. The analysis of the breadth of traffic lanes at the entrance manoeuvre to the Mrzezyno port and the manoeuvre of turning was carried out in the aspect of defining the conditions for safe manoeuvring. By analysing the breadth of traffic lanes for entrance manoeuvres to the Mrzezyno port, it can be noticed that it meets the conditions for safe vessel entrance and requires minor corrections. A detailed analysis was included in the conclusions. Figure 7 presents overall series -85 passages. 


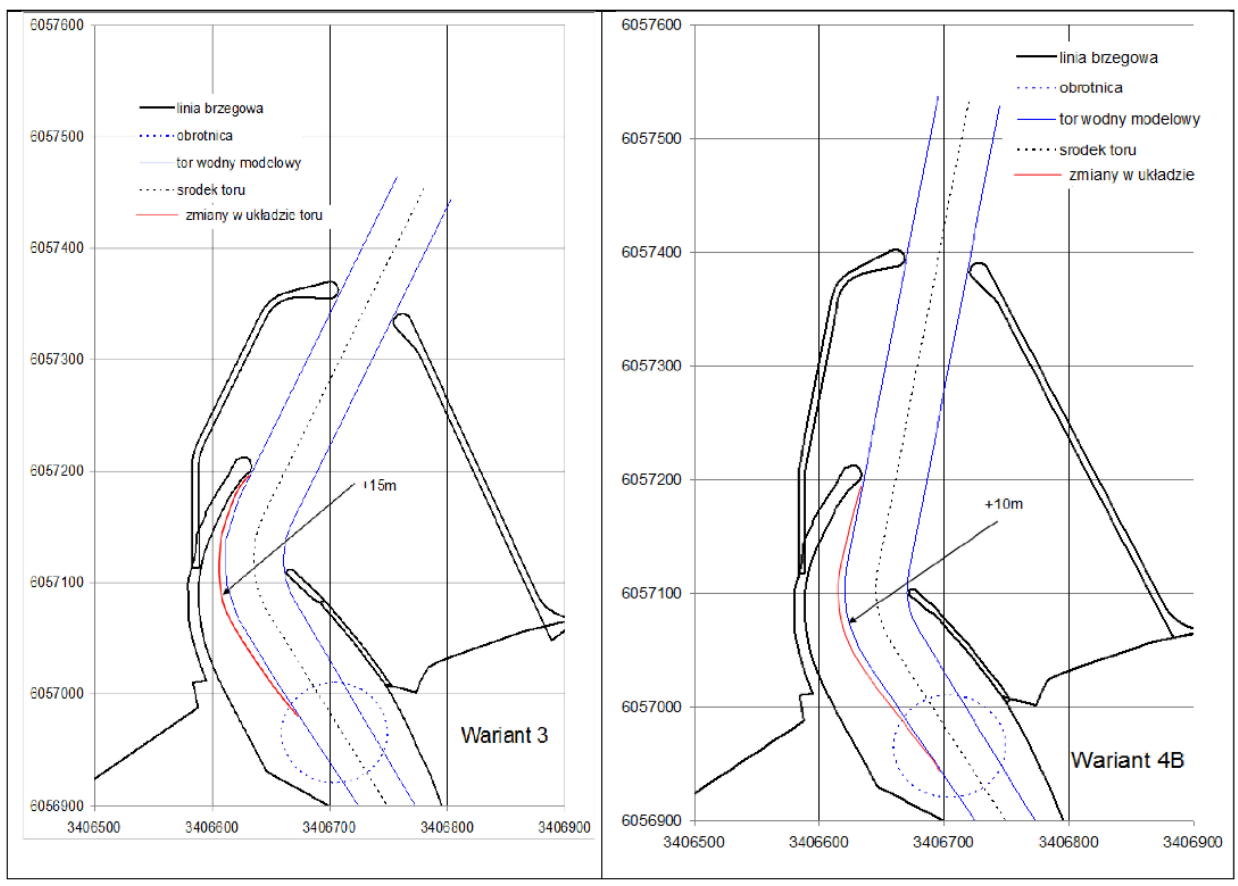

Fig. 7. A graphic comparison of simulation results for the variants 3 and $4 \mathrm{~b}$ of a vessel of the Adler type

\section{CONCLUSIONS}

The studies presented can be used for the modernization of the port and breakwater in Mrzezyno. The conclusions with respect to the conditions of safe manoeuvring a passenger ship can be formulated as follows:

1. The $4 \mathrm{~B}$ variant is more beneficial from the navigational point of view due to a smaller change of the course for the curve in the vicinity of the old breakwater.

2. The entrance to the port is possible for winds up to $17 \mathrm{~m} / \mathrm{s}$ from any direction for both variants.

3. There is no need to change the layout of breakwaters either external or internal.

4. Passing a sea lane is possible with a wind of up to $17 \mathrm{~m} / \mathrm{s}$ provided that some minor changes in the layout of the sea lane are introduced, i.e. widening it by $10 \mathrm{~m}$ in the vicinity of the curve for the variant $4 \mathrm{~B}$ and by $15 \mathrm{~m}$ for variant 3 . Picture 7 the corrected layout of the lane that takes into account the simulation results for the test conditions (wind of up to $17 \mathrm{~m} / \mathrm{s}$ ). 
5. The outermost west part of the pulled down old east breakwater should be protected with a scarp or a sheet piling with fenders that allow for the vessel to lean against them in the case of problems at manoeuvring when entering the port.

6. Selected aspects of manoeuvring in a port were presented.

\section{REFERENCES}

[1] Artyszuk J., Towards a Scaled Manoeuvring Mathematical Model for a Ship of Arbitrary Size, Scientific Bulletin of Maritime University of Szczecin No. 6, 2005, pp. 21-37.

[2] Computer simulation for new port design in Mrzeżyno, unpublished report [in Polish], Maritime University, Szczecin 2012.

[3] Gucma L., Risk modelling of ships collision factors with fixed port and offshore structures [in Polish], Publ. Maritime University, Szczecin 2005.

[4] Gucma L., Risk assessment in bridge area in respect to ship — bridge collision [in Polish], Publ. Maritime University, Szczecin 2012.

[5] Gucma S., Methods of delimitation and formation water routes [in Polish], Publ. WSM, Szczecin 1990.

[6] Gucma S., Marine Traffic Engineering [in Polish], Publ. Okrętownictwo i Żegluga, Gdańsk 2001.

[7] Gucma S., Simulation research methods in marine traffic engineering [in Polish] Publ Akademia Morska, Szczecin 2008.

[8] Iribarren J.R., Determining the horizontal dimensions of ship maneuvering areas. PIANC Bulletin No. 100, Bruxelles 1999.

[9] PIANC: Approach Channels. A Guide for Design. Final Report of the Joint PIANCIAPH Working group II-30 in cooperation with IMPA and IALA, June 1997.

[10] USACE, United States Army Corps of Engineers: Hydraulic Design of Deep-Draft Navigation Projects, Washington 2006.

[11] Recommendations for the design of marine hydrotechnical constructions [in Polish], ed. B. Mazurkiewicz, Technical University of Gdańsk, Gdańsk 2006.

Received October 2016

Reviewed June 2017

Published 12.01.2018 


\section{RENATA BOĆ}

Maritime University of Szczecin

Wały Chrobrego 1-2 Str., 70-500 Szczecin, Poland

e-mail: r.boc@am.szczecin.pl

\section{LUCJAN GUCMA}

Maritime University of Szczecin

Wały Chrobrego 1-2 Str., 70-500 Szczecin, Poland

e-mail:1.gucma@am.szczecin.pl

\section{ANDRZEJ BĄK}

Maritime University of Szczecin

Wały Chrobrego 1-2 Str., 70-500 Szczecin, Poland

e-mail: a.bak@am.szczecin.pl

\section{STRESZCZENIE}

Można wskazać wiele obiektywnych przyczyn powodujących zainteresowanie decydentów przebudową istniejących falochronów, a niekiedy znacznych fragmentów portów. Należą do nich między innymi zmiany klimatyczne, zwiększanie się wymiarów statków, a niekiedy niepraktyczność aktualnych rozwiązań. W takich przypadkach bardzo przydatne są metody symulacyjne, które pozwalają na gruntowną analizę możliwych wariantów modernizacji, biorąc pod uwagę zmienność podstawowych parametrów. W artykule przedstawiono wyniki badań nad optymalizacją portu morskiego Mrzeżyno w kontekście bezpieczeństwa nawigacji i możliwości obsługi większych statków po wprowadzeniu modernizacji. Zastosowano metody symulacji manewrów w czasie rzeczywistym, rozważając dwa różne warianty, które z technicznego punktu widzenia mogłyby zostać wdrożone. Uwzględniając wielostronną analizę możliwości ułatwienia manewrów w porcie oraz bezpieczeństwo nawigacyjne, wskazano wariant optymalny. 